\title{
ARTYKUtY
}

Klio. Czasopismo poświęcone dziejom Polski i powszechnym

PL ISSN 1643-8191, t. 31 (4)/2014, s. 43-72

(c) (1) $\Theta$

http://dx.doi.org/10.12775/KLIO.2014.057

KATARZYNA KURAS

(Kraków)

\section{Teatr śmierci u służbie majestatu. Trzy exempla z dziejów Rzeczypospolitej XVII i XVIII wieku}

Kól Francji Ludwik XIV umierał dostojnie i na oczach całego dworu. —Była to śmierć publiczna, której towarzyszyła narastająca świadomość jej uczestników - rodziny, dworzan, urzędników - w jakiego rodzaju spektaklu przyszło im uczestniczyć. Finał sztuki odgrywanej akt po akcie w ciągu sierpnia 1715 roku był w zasadzie z góry znany: władca miał 77 lat, a gangrena, która powoli, acz systematycznie zajmowała kolejne partie królewskiej nogi, nie pozostawiała złudzeń co do możliwego zakończenia tej historii. Było ono dla wszystkich oczywiste od momentu, gdy 24 sierpnia 1715 roku uznano, że jest za późno na amputację chorej kończyny. Osiemnastowieczna medycyna, reprezentowana przez najsłynniejszych paryskich chirurgów, była bezradna wobec takiego stanu rzeczy.

Stan zdrowia króla znacząco pogorszył się już na przełomie lipca i sierpnia 1715 roku. Początkowo nie zdawano sobie sprawy z przyczyny dolegliwości, a bóle w lewej nodze i utratę apetytu łączono raczej z podagrą, na którą Ludwik XIV cierpiał od lat, niż z innymi chorobami. „Król 
Słońce" w miarę możliwości nie ograniczał swej aktywności - przewodniczył obradom Rady Państwa oraz uczestniczył w uroczystościach religijnych. Wyjątek stanowił dzień 14 sierpnia, gdy ze względu na ból w nodze monarcha odwołał ceremonię lever. Jak napisał jeden $\mathrm{z}$ jego biografów: „Tradycyjny porządek został złamany i dwór wiedział już, że król jest poważnie chory, bardziej niż w 1686 roku, gdy przeszedł operację"1. Król był zmuszony opuścić mszę świętą, co wzbudziło szereg domysłów i plotek na temat jego stanu zdrowia ${ }^{2}$. Życie w Wersalu polegało w dużej mierze na stwarzaniu pozorów, więc następnego dnia ceremonia królewskiego lever już się odbyła, a sam monarcha, udając się na mszę 15 sierpnia w dzień Wniebowzięcia Matki Bożej, o własnych siłach przedefilował przez Galerię Zwierciadlaną. Jego cel był oczywisty dla współczesnych: Ludwikowi XIV zależało na tym, by zademonstrować poprawę swej formy przed jak największą liczbą dworzan ${ }^{3}$. Następnie król spożywał obiad, co prawda w łóżku, ale za to w otoczeniu widzów. Wszyscy wiedzieli, że rozpoczęło się ostatnie przedstawienie, w którym monarcha był głównym aktorem. Jego ambicją i celem było zaś to, by swą finalną rolę odegrać perfekcyjnie. W miarę upływu czasu i utraty sił, król nie zdobywał się już na tak heroiczne gesty jak ten z 15 sierpnia. Starał się jednak być widoczny i dostępny dla swych poddanych. Przyjmował dostojników państwowych, spędzał czas w towarzystwie sporej grupy dworzan, a parokrotnie zażądał nawet koncertu grupy włoskich muzyków. Podczas wieczoru spędzonego 22 sierpnia w jego grand cabinet panował tak wielki tłok, że z trudem można było się tam przedostać ${ }^{4}$. Wszystko to działo się w okresie, gdy nie było już realnej nadziei na poprawę stanu zdrowia monarchy. Król miał świadomość powagi sytuacji i zadowalał się ceremonialnymi pozorami władzy. Nie zdecydował się natomiast na rozdanie beneficjów kościelnych, mimo nacisków ze strony spowiednika, ojca Le Tellier5. W ostatnich dniach nie podejmował żadnych ważnych decyzji. 26 sierpnia spotkał się z delfinem Ludwikiem, któremu

${ }^{1}$ V. Cronin, Ludwik XIV, Warszawa 2001, s. 354.

2 Saint-Simon, Mémoires, wyd. E. Truc, Paris 1950, t. 4, s. 878.

${ }^{3} \mathrm{~V}$. Cronin wspomina, że król został zaniesiony na mszę, co nie znajduje potwierdzenia w: La mort de Louis XIV. Journal des Antoine, ed. E. Drumont, Paris 1880, s. 20.

${ }^{4}$ Ibidem, s. 36.

5 Ibidem, s. 21. 
symbolicznie przekazał władzę i udzielił królewskiego błogosławieństwa. Jego śmierć w Wersalu 1 września 1715 roku nie była dla nikogo zaskoczeniem, zwłaszcza że nastąpiła po okresie kilkudniowej agonii, w trakcie której król na przemian tracił świadomość i ją odzyskiwał ${ }^{6}$.

Publiczna śmierć Ludwika XIV już na współczesnych sprawiała wrażenie starannie zaaranżowanego widowiska. Dangeau zanotował, że król zgasł niczym świeca ${ }^{7}$. Księżna d'Orléans określiła jego ostatnie dni jako "le spectacle le plus triste et le plus touchant, qu'on puisse imaginer". Według licznych opinii król przyjmował swój ziemski koniec z godnością właściwą Bożemu pomazańcowi ${ }^{9}$. Obserwatorzy tych wydarzeń podkreślali, że znosił fizyczny ból z cierpliwością, nie epatował chorobą, ale był zarazem zdecydowany na podejmowanie wszelkich ryzykownych terapii, łącznie z amputacją nogi, która na wczesnym etapie mogła przedłużyć jego życie ${ }^{10}$. Dla współczesnych postawa ta była równoznaczna $\mathrm{z}$ iście królewską odwagą. Umieranie monarchy odbywało się w podniosłej i religijnej atmosferze, z zachowaniem wszelkich chrześcijańskich powinności. Pani de Maintenon w liście do królewskiego lekarza Fagona napisała nawet, że Ludwik XIV odchodził z tego świata niczym człowiek święty ${ }^{11}$.

W kontekście widowiskowej śmierci Ludwika XIV rodzi się pytanie, w jakich okolicznościach umierali polscy królowie w epoce nowożytnej? Nie chodzi tu bynajmniej o rozważania nad medycznymi przyczynami poszczególnych zgonów, bo jest to temat dobrze znany i dokładnie opracowany, ale o fenomen królewskiej śmierci, a zwłaszcza o oprawę jej towarzyszą-

${ }^{6}$ Ibidem, s. 71.

7 Mémoires sur la mort de Louis XIV par le marquis de Dangeau, Paris 1858, s. 32.

${ }^{8}$ Ibidem, s. 8, Elżbieta Karolina, księżniczka d'Orléans do Ludwiki Bawarskiej, Wersal, 27 VIII 1715. Podobnymi słowami rozpoczął swój opis ostatnich dni króla markiz Dangeau.

${ }^{9}$ La mort de Louis XIV..., s. 66.

${ }^{10} \mathrm{~W}$ zaawansowanym stadium choroby król zwracał się do swego chirurga Charles'a George'a Mareschala: „Maréchal, n'avez-vous pas là des rasoirs? Coupez! Et ne craignez rien”. P. Narbonne, Journal des règnes de Louis XIV et Louis XV de l'année 1701 à l'année 1744, ed. J.-A. Roi, Paris 1866, s. 44.

11 Ostatni miesiąc Ludwika XIV jest doskonale znany i opracowany w literaturze historycznej. Biologiczną i społeczną kronikę królewskiego zgonu przedstawił S. Perez, La santé de Louis XIV. Une biohistoire du Roi-Soleil, Paris 2007, s. 148-162. 
cą (oprawę momentu śmierci, ale już nie ceremonii funeralnych). Zabieg wpisania śmierci kolejnych polskich królów elekcyjnych w konwencję spektaklu jest oczywiście kontrowersyjny, jednak to dzięki niemu udaje się zdefiniować znaczenie tego momentu w trwaniu bądź umacnianiu monarszego majestatu ${ }^{12}$. To generuje również szereg problemów badawczych. Czy polscy królowie elekcyjni, sprawujący swój urząd od momentu koronacji do śmierci, mieli w ogóle motywację, by w chwili zgonu dbać o propagandę swej królewskiej osoby, skoro nie mogli liczyć na przekazanie władzy swemu potomstwu (wyjąwszy niepewne nadzieje na zwycięstwo syna podczas wolnej elekcji)? Kolejne kwestie: w jakich miejscach polscy królowie umierali i czy niosło to ze sobą jakiekolwiek treści ideologiczne oraz kto był obecny przy nich w okresie poprzedzającym i w momencie samego zgonu? Czy istniał kanon zachowania w obliczu królewskiej śmierci, a może chwile te bywały wykorzystywane w celu zyskiwania monarszej łaski bądź załatwiania prywatnych interesów? Odpowiedzi na tak postawione pytania powinny prowadzić do wzbogacenia dość skąpych w polskiej historiografii studiów nad królewskim majestatem, balansując na granicy historii władzy oraz biohistorii ${ }^{13}$. Koncentracja na finalnym etapie życia monarchy elekcyjnego nie jest bynajmniej próbą podjęcia rozważań nad dwoma ciałami króla, gdyż implementacja tej koncepcji na terenie Rzeczypospolitej oraz sakralizacja władzy monarszej miały ograniczony charakter, podobnie zresztą jak w Hiszpanii ${ }^{14}$. W istocie chodzi o odpowiedź na pytanie - czy monarcha elekcyjny, znajdując się u kresu swych dni, umierał jako król, czyli Boży pomazaniec namaszczony przed laty w trakcie koronacji ${ }^{15}$, czy też

12 Zagadnienia związane ze zgonami monarchów zyskują na popularności w ostatnich latach, powstają na ten temat kolejne studia, np. Les funérailles princières en Europe, XVIe-XVIIIe siècle, vol. 1, Le grand théâtre de la mort, red. J. A. Chrościcki, M. Hengerer, G. Sabatier, The „Aulica” Collection 2012; Les derniers jours des rois, ed. P. Gueniffey, Perrin 2014.

13 Najnowsza literatura przedmiotu w pracy U. Augustyniak, Wazowie i „królowie rodacy", Warszawa 1999, s. 103-119.

${ }_{14}$ T. F. Ruiz, Une royauté sans sacre: la monarchie castillane du bas Moyen-Âge, „Annales. Économies, Sociétés, Civlilisations” 1984, vol. 39, z. 3, s. 429-453.

15 U. Augustyniak, op. cit., s. 67-71 oraz M. Markiewicz, Sakralizacja wtadzy królewskiej w czasach nowożytnych, [w:] Staropolski ogląd świata. Kultura staropolska - poszukiwanie sacrum, odnajdywanie profanum, red. B. Rok, F. Wolański, Toruń 2013, s. 27-34. 
zwykły śmiertelnik - zaledwie partner w układzie politycznym zawartym niegdyś ze szlachtą podczas wolnej elekcji. W tym drugim wypadku naturalne wydawałoby się przede wszystkim ubolewanie nad dolegliwościami ciała i przypisaną mu marnością ${ }^{16}$. Co wreszcie działo się z królewskim majestatem, wyjątkowo cenionym przez szlacheckich poddanych, w momencie śmierci króla: czy umierał wraz z odchodzącym władcą? ${ }^{17}$

To tylko niektóre kwestie wyłaniające się podczas analizy paradoksu królewskiego majestatu uosobionego w śmiertelnym ciele ${ }^{18}$. W niniejszym artykule zostaną zaprezentowane zarówno wszelkie symptomy związane z oprawą królewskich zgonów, jak i - w miarę możliwości - sposób postrzegania tego zagadnienia przez współczesnych, ze zwróceniem szczególnej uwagi na osoby obecne w okresie poprzedzającym królewską śmierć, niekiedy również w jej trakcie. Analizą zostały objęte śmierci tylko trzech polskich monarchów; w ich przypadku troska o oprawę ceremonialną ostatnich chwil była wyraźna, nawiązując do ars bene moriendi stosownej dla osoby panującego. Wykluczono śmierci, które odbywały się w warunkach nadzwyczajnych (i najczęściej wykluczały jakikolwiek ceremoniał) lub też nie miały miejsca na terytorium Rzeczypospolitej. Z tego względu poza zasięgiem zainteresowań znalazła się postać Henryka Walezego, zasztyletowanego we Francji w 1589 roku, Stefana Batorego ${ }^{19}$ oraz Władysława IV Wazy ${ }^{20}$, którzy zmarli w sposób nagły, Jana Kazimierza Wazy, który

Określanie monarchy polskiego mianem „pomazańca bożego” może nie jest zbyt częste, ale z całą pewnością występuje w źródłach: „Króla JMci, jako pomazańca bożego nigdy źle nie wspominaj, owszem, przed źle wspominającymi ochraniaj”, cyt. za: W. Czapliński, J. Długosz, Życie codzienne magnaterii polskiej w XVII wieku, Warszawa 1976, s. 180.

${ }^{16}$ Por. analizę zakresu szacunku i czci względem osoby monarchy: E. Opaliński, Kultura polityczna szlachty polskiej $w$ latach 1587-1652, Warszawa 1995, s. 54-55.

${ }^{17}$ E. Opaliński, Postawa szlachty polskiej wobec osoby królewskiej jako instytucji $w$ latach 1587-1648. Próba postawienia problematyki, „Kwartalnik Historyczny” 1983, R. 90 , nr 4, s. 797.

${ }^{18}$ La mort de rois, précédé de Les rois meurent un jour par S. Perez, Grenoble 2006, s. $15-16$.

${ }^{19}$ F. Giedroyć, Przyczyna zgonu króla Stefana Batorego, „Przegląd Historyczny” 1906, t. 2, s. 143-156, 277-290.

${ }^{20}$ F. Giedroyć, Król Wtadystaw IV (Historia choroby), „Krytyka Lekarska” 1903, R. 7, s. 79-82; H. Wisner, Wtadystaw IV Waza, Wrocław 2009, s. 150-151, 176. Władysław IV konał przez kilka dni, a w Mereczu towarzyszyli mu głównie lekarze oraz duchowni. 
po abdykacji w 1668 roku dokonał żywota w jednym z klasztorów we Francji, Augusta III Sasa, który odszedł w Dreźnie oraz Stanisława Augusta Poniatowskiego, który zmarł w 1798 roku w Pałacu Marmurowym w Petersburgu, abdykowawszy wcześniej. Pewne wątpliwości budzą natomiast okoliczności zgonu Michała Korybuta Wiśniowieckiego, który zmarł 10 listopada 1673 roku we Lwowie ${ }^{21}$. Złą formę króla zauważano co najmniej od 13 października t.r., jednak ze względu na wiek monarchy dość długo uważano jego dolegliwości za przejściowe. 3 listopada stan Michała Korybuta był na tyle ciężki, że spodziewano się jego śmierci; król w najbliższych dniach sporządził testament i podpisał ostatnie w swym życiu dokumenty. Jego śmierci - zapewne przez fakt, że odbywała się w nadzwyczajnych okolicznościach (wyprawa wojenna) i miejscu (kamienica arcybiskupów lwowskich przy Rynku) - nie towarzyszyła jednak żadna szczególna ceremonialna oprawa ${ }^{22}$.

Zastosowane kryteria pozwalają objąć analizą w sygnalizowanej materii właściwie tylko zgony Zygmunta III Wazy w 1632 roku, Jana III Sobieskiego w 1696 roku oraz Augusta II Sasa w 1733 roku. Pewne wątpliwości mogą powstać w przypadku śmierci Władysława IV Wazy oraz Jana III Sobieskiego, gdyż długa choroba obu monarchów w zasadzie nie pozwala precyzyjnie wyznaczyć finalnego etapu ich życia. O ile jednak w przypadku pierwszego z nich nieoczekiwany zgon był efektem wieloletnich dolegliwości ciała, a zwłaszcza nieodpowiedniego trybu życia ${ }^{23}$, to już

${ }^{21}$ K. Przyboś, Itinerarium króla Michata Korybuta Wiśniowieckiego, 1669-1673, [w:] Studia Historyczno-Prawne, red. J. Dorobisz, W. Kaczorowski, Opole 2004, s. 259.

${ }^{22}$ Informacje o ostatnich dniach Michała Korybuta Wiśniowieckiego w: J. T. Józefowicz, Kronika miasta Lwowa od r. 1634 do 1690, tłum. M. Piwocki, Lwów 1854, s. 329-338; Ojczyste spominki w pismach do dziejów dawnej Polski, wyd. A. Grabowski, t. 2, Kraków 1845, s. 269-277; Pisma do wieku i spraw Jana Sobieskiego, wyd. F. Kluczycki, Kraków 1880, t. 1, cz. 1, s. 1312; Epistolae historico-familiares, Braniewo 1711, t. 1, s. 479; W. Kochowski, Roczniki polskie. Klimakter czwarty (1669-1673), Warszawa 2011, s. 349358. W. Kochowski wspomina tu o obecności przy śmierci króla podkanclerzego Andrzeja Olszewskiego oraz starosty narewskiego Felicjana Wąsowicza.

${ }^{23}$ Rumbold z Połocka, Zdrowie Wtadystawa IV, „Przegląd Historyczny” 1911, t. 13, z. 1, s. 1-23. Władysław IV był regularnie przykuwany do łóżka z powodu napadów podagry, co sprawiło, że jego poddani przyzwyczaili się do widoku króla transportowanego na noszach do Izby Poselskiej, Senatu, na mszę św., a nawet do teatru. Cały sejm w 1646 r. 
w przypadku starego i schorowanego Jana III Sobieskiego można wyznaczyć finalny etap, gdy jego rodzina i otoczenie zdawali sobie sprawę z tego, co nieuniknione.

Tak przeprowadzona selekcja i ograniczenie analizy do trzech przypadków nie wyklucza zarazem silnego oddźwięku w szerokich kręgach społeczeństwa szlacheckiego wywołanego każdorazowym zgonem monarchy. Teatr śmierci nie dotyczył przecież wyłącznie warstwy ceremonialnej (analizowanej w niniejszym artykule), ale rozgrywał się w szerszym kontekście wydarzeń politycznych związanych z koniecznością elekcji nowego króla. Był ważnym tematem zarówno dla zgromadzonych w stolicy senatorów, jak i obywateli wyczekujących na nowinę o zbliżającym się wyborze władcy, a polityczne i propagandowe znaczenie królewskich śmierci znacznie wykraczało poza ramy ars bene moriendi.

\section{Zygmunt III Waza}

Informacje o wpływie zdrowia Zygmunta III na sprawowanie rządów pochodzą już z 1628 roku. 27 czerwca t.r. odnotowano jedną z nielicznych w skali całego jego panowania nieobecność podczas nabożeństwa inaugurującego obrady sejmowe. Choroba nie ustępowała, więc monarchę wnoszono na posiedzenia na specjalnie skonstruowanym krześle ${ }^{24}$. Problemy zdrowotne trapiły króla w ciągu najbliższych lat, jednak znaczne ich pogorszenie wiązano ze śmiercią królowej Konstancji w czerwcu 1631 roku, która miała spowodować załamanie monarchy ${ }^{25}$. Podagra, paraliż ręki oraz krwotoki $\mathrm{z}$ nosa w znacznym stopniu utrudniały mu sprawowanie rządów w ostatnich latach ${ }^{26}$. Jednak schorowany monarcha

król w zasadzie spędził w łóżku. Zob.: M. Vorbek-Lettow, Skarbnica Pamięci. Pamiętnik lekarza króla Wtadystawa IV, wyd. E. Galos, F. Mincer, Wrocław 2006, s. 152-154.

${ }^{24}$ W. Kaczorowski, Choroba i prawdopodobna przyczyna zgonu Zygmunta III Wazy, „Archiwum Historii Medycyny” 1982, t. 45, s. 46-47.

${ }_{25}$ Biblioteka Naukowa PAU i PAN w Krakowie (dalej: BPAN), rkps 8403 (Teki Rzymskie t. 63), s. 197-198.

${ }^{26}$ J. Seredyka, Rzeczpospolita w ostatnich latach panowania Zygmunta III (1629-1632). Zarys wewnętrznych dziejów politycznych, Opole 1978, s. 141-142. Tu informacja, 
przetrwał obrady sejmu w 1632 roku, co napawało współczesnych sporym optymizmem ${ }^{27}$.

Dnia 22 kwietnia 1632 roku władca udał się do Opacza, gdzie został przyjęty i ugoszczony przez podkomorzego warszawskiego Zygmunta Opackiego ${ }^{28}$. Wrócił do Warszawy jeszcze tego samego dnia; nazajutrz czuł się znacznie gorzej. Dwa dni po wyprawie do Opacza, 24 kwietnia, Zygmunt III opuścił mszę świętą, a królewskie otoczenie zwróciło uwagę na jego zły wygląd ${ }^{29}$. Załamanie jego stanu zdrowia nastąpiło w nocy $24 / 25$ kwietnia. Rano około godziny 8.00 król został znaleziony w pozycji leżącej, z twarzą na wznak, w dodatku objętą jednostronnym paraliżem. Najbliższe minuty poświęcono na zabiegi lekarskie - po dwóch godzinach paraliż częściowo ustąpił, a Zygmunt III, zapewne mając już świadomość swego stanu, wezwał spowiednika, jezuitę Andrzeja Markwarta i odbył spowiedźz ${ }^{30}$.

Niewiele wiadomo o kolejnym dniu agonii monarchy, czyli 26 kwietnia. Wiadomości na ten temat pochodzą w zasadzie tylko z pamiętników Albrychta Stanisława Radziwiłła. Włodzimierz Kaczorowski przypuszcza, że brak danych wynikał ze świadomej polityki ścisłego otoczenia króla, przede wszystkim wojewody derpskiego Kaspra Denhoffa ${ }^{31}$ oraz ochmistrzyni dworu Urszuli Meierin ${ }^{32}$. W tym dniu do króla dopuszczani byli wyłącznie

że Zygmunt III okresowo nie podpisywał listów, ale wydawał ustne polecenia. Z drugiej jednak strony wiadomo, że znajdujący się w złym zdrowiu monarcha składał swój podpis pod legacją sejmikową w $1632 \mathrm{r}$.

27 Zdaniem H. Wisnera stan zdrowia monarchy mógł pod koniec jego życia wpływać na spowolnienie działania machiny państwowej. Idem, Zygmunt III Waza, Wrocław 2006, s. 235. O stopniowym pogarszaniu królewskiego zdrowia m.in. M. Vorbek-Lettow, op. cit., s. 78.

${ }^{28}$ A. S. Radziwiłł, Pamiętnik o dziejach w Polsce, przeł. A. Przyboś, R. Żelewski, t. 1, Warszawa 1980, s. 106-107. Według niektórych źródeł 23 IV. BPAN, rkps 8403 (Teki Rzymskie t. 63), s. 201.

${ }^{29} \mathrm{Na}$ temat wyglądu króla: m.in. Mikołaj Tryzna, kuchmistrz litewski oraz nuncjusz H. Visconti. Zob.: W. Kaczorowski, op. cit., s. 50.

${ }^{30}$ A. S. Radziwiłł, op. cit., s. 108.

31 O K. Denhoffie: W. Leitsch, Das Leben an Hof König Sigismundus III. von Polen, Bd. 3, Wien 2009, s. 1922-1933.

${ }^{32}$ Wieloletnia silna pozycja U. Meierin na dworze Wazów pozostaje bezprecedensowym fenomenem. Zob.: B. Fabiani, Życie codzienne na Zamku Królewskim w epoce Wazów, 
lekarze oraz duchowni. Nawet potomstwo Zygmunta III nie miało pełnego obrazu faktycznego stanu zdrowia ojca. Strategia decydentów (Denhoffa, Meierin, a może samego króla?) polegała nawet nie tyle na braku informacji, co na dezinformacji. Na dworze krążyły plotki, że Zygmunt III wstaje z łóżka, przechadza się po pokoju i własnoręcznie podpisuje listy. Pojawiła się nawet informacja, że listy są sygnowane ręką monarchy, „ale krzywo” ${ }^{33}$. Według W. Kaczorowskiego wątpliwe jest, by dane te odzwierciedlały stan faktyczny, miały na celu raczej uspokojenie królewskiej rodziny oraz senatorów. W jego opinii dystrybuujący te pogłoski liczyli na radykalną poprawę zdrowia króla, co zresztą miało już miejsce kilkakrotnie ${ }^{34}$. Istotnie, jest mało prawdopodobne, by rozsiewane plotki były prawdziwe, skoro już następnego dnia (27 kwietnia) stan zdrowia króla był krytyczny. Pozostaje jednak pytanie, w jakim celu rozpuszczano fałszywe informacje na temat rzekomej poprawy królewskiego zdrowia i jakie cele chciano w ten sposób osiągnąć?

Nie ulega wątpliwości, że 26 kwietnia za zamkniętymi drzwiami królewskiej komnaty rozgrywała się istotna część spektaklu końca życia. Problemem jest jednak brak źródeł, który skazuje historyka na hipotetyczne rekonstruowanie przebiegu tego dnia ${ }^{35}$. Prawdę znały na pewno trzy osoby - król (o ile był przytomny), K. Denhoff oraz U. Meierin, jednak żadne z nich nie pozostawiło danych pozwalających na rozwikłanie tej zagadki. Gdyby tego dnia, 26 kwietnia, nie podawano żadnych informacji o stanie zdrowia króla, sprawa byłaby prostsza. Można by domniemywać, że doszło do załamania stanu fizycznego bądź psychicznego monarchy; stworzona bariera mogłaby wynikać również z rozkazów wydanych przez samego Zygmunta III, który mógł sobie nie życzyć kontaktów z rodziną bądź z poddanymi. Prawdziwą zagadką są jednak rozsiewane pogłoski na temat poprawy zdrowia króla, które w dodatku najwyraźniej były fałszy-

Warszawa 1996, s. 76-78. O wpływach U. Meierin: W. Czapliński, W. Leitsch, Meierin Urszula, PSB, t. 20, Wrocław 1975, s. 385-387; W. Leitsch, op. cit., s. 1848-1922.

33 A. S. Radziwiłł, op. cit., s. 108.

34 W. Kaczorowski, op. cit., s. 50-51.

35 Część badaczy, w tym J. Seredyka, przyjęła, że 26 kwietnia monarcha faktycznie czuł się dużo lepiej. Idem, op. cit., s. 209-210. Dokładna relacja przebiegu tego dnia w: W. Leitsch, Das Leben an Hof, Bd. II, s. 1041. 
we. (Gdyby były prawdziwe, dlaczego ograniczano by kontakty z monarchą? Lepsze samopoczucie króla mogło tylko podtrzymać wiarę poddanych w jego wyzdrowienie!). Być może kluczem do rozwikłania zagadki jest zdanie: „Podpisał jeszcze kilka pism ręką własną, ale krzywo” ${ }^{36}$, prowadzące na trop różnego rodzaju interesów, które tego dnia mogły być załatwiane za zamkniętymi drzwiami królewskiej komnaty, w tym o odczytaną następnego dnia deklarację królewską oraz rozdane wakanse.

Dnia 27 kwietnia stan zdrowia Zygmunta III był na tyle zły, że otoczenie nie mogło już dłużej ukrywać prawdy. Do obecnych w stolicy senatorów wysłano informację, że król kona; podobna wiadomość została ekspediowana do przebywającego na łowach w odległości około 9 mil od Warszawy najstarszego syna królewskiego, Władysława ${ }^{37}$. Dlaczego jednak Władysław opuścił stolicę i pojechał na łowy w sytuacji, gdy życie jego ojca było zagrożone? Oczywiście mógł poczuć się uspokojony doniesieniami z 26 kwietnia, jednak wydaje się to mało prawdopodobne. Raczej był to celowy manewr, doskonale wpisujący się w dramaturgię wydarzeń, które rozegrały się 27 kwietnia na Zamku Królewskim w Warszawie.

Zgromadzeni senatorowie zostali tego dnia dopuszczeni do królewskiego łoża około godziny 10.00, po tym jak monarcha otrzymał sakrament ostatniego namaszczenia. Ujrzeli człowieka „pozbawionego mowy, z wykrzywionymi z prawej strony ustami i unieruchomionym paraliżem lewym okiem"38. Najważniejsze miało się jednak dopiero wydarzyć:

Wtedy zaczęła do nas mówić czcigodna Urszula, polecając naszej opiece potomstwo króla i przypominając każdemu z nas otrzymane z jego rąk dobrodziejstwa. Przez z górą 44 lata szczę́liwego panowania zasłużył sobie król na taką od nas wdzięczność, abyśmy zachowali pamięć o nim okazując to najjaśniejszym jego dzieciom ${ }^{39}$.

36 A. S. Radziwiłł, op. cit., s. 108.

37 Do nieprawdziwych należy wersja, jakoby Władysław przebywał za granicą w czasie choroby ojca, podana w: Kronice Pawta Piaseckiego biskupa przemyślskiego, Kraków 1870 , s. 354.

38 A. S. Radziwiłł, op. cit., s. 108. Monarcha był przewiązany długim, czerwonym, jedwabnym sznurem, nosił czarną, jedwabną czapeczkę i leżał na wpół uniesiony.

39 Ibidem, s. 109. 
Król właśnie w tym momencie z trudem zrzucił z głowy swą czarną, jedwabną czapeczkę i choć U. Meierin próbowała mu ją z powrotem nałożyć, nie pozwolił tego uczynić aż do momentu zakończenia przemówienia na temat przyszłości swego potomstwa. Dopiero później „z pomocą Urszuli włożył ją sobie na głowę ${ }^{40}$. Przez zgromadzonych senatorów gest ten został zinterpretowany jako akceptacja mowy wygłoszonej przez ochmistrzynię.

Po ogłoszeniu królewskiej deklaracji w sprawie potomstwa, doszło do rozdania wakansów. Czekano z tym na przybycie większej liczby senatorów (dokładna godzina nie jest znana). Wolę monarchy ponownie zaprezentowała U. Meierin - podskarbstwo wielkie koronne otrzymał Jan Mikołaj Daniłowicz. Co ciekawe, kanclerz Jakub Zadzik zadał w tej sytuacji Zygmuntowi III pytanie, czy przekazuje podskarbiemu nadwornemu podskarbstwo wielkie? Monarcha nie był w stanie werbalnie potwierdzić swej nominacji, podniósł tylko rękę. Analogiczny problem pojawił się, gdy ochmistrzyni ogłosiła, iż wakujące podskarbstwo nadworne obejmuje Jerzy Ossoliński. Tym razem kanclerz, prosząc o potwierdzenie tej informacji, zasugerował, że wystarczy królewski gest. „[Król] dał znak ręką i głośno, choć nie dość wyraźnie, powiedział po polsku: ‘daję’”, po czym podnosząc obie ręce wyraził zgodę, by podskarbiowie złożyli przy jego łożu przysięgę ${ }^{41}$.

Okoliczności rozdania wakansów w dniu 27 kwietnia 1632 roku pokazują, jak wielkie znaczenie przywiązywano do formy i dbałości o legalność $\mathrm{w}$ podejmowaniu decyzji, nawet $\mathrm{w}$ sytuacji, gdy monarcha dystrybuujący wakanse znajdował się na łożu śmierci. Stąd pytania kanclerza, których celem było uzyskanie królewskiego potwierdzenia w formie werbalnej deklaracji bądź gestu akceptacji treści ogłoszonej przez osobę zaufaną, choć postronną z punktu widzenia szlachty. Chodziło o to, by rozwiać wszelkie ewentualne wątpliwości co do legalności monarszej woli w sytuacji, gdy Zygmunt III nie był już w stanie ogłosić jej osobiście. Dbałość o formę oraz natychmiastowość złożenia przysięgi przez nowych podskarbich miały pozbawić argumentów przeciwników ostatnich personalnych decyzji króla. Panowało przeświadczenie, że paraliż zajął lewą stronę królewskiego ciała,

\footnotetext{
${ }^{40}$ Ibidem.

41 Ibidem.
} 
jednak „nie odjął mowy i władzy” ${ }^{42}$. „Mowa” umożliwiała w tym wypadku sprawowanie przez monarchę realnej władzy. Ceremonie ogłoszenia królewskiej woli zakończyły się do południa, kiedy stan zdrowia monarchy gwałtownie się pogorszył ${ }^{43}$.

Co ciekawe, podczas tych wydarzeń nie był obecny królewicz Władysław, choć posłano po niego już przed godziną 9.00. Przypuszczenia, że nie zdążył przybyć na czas, są mało prawdopodobne. Królewicz dotarł na zamek dopiero wieczorem (ok. godziny 21.00), choć polował w okolicach Płońska. Zarówno tajemnica rzekomego polepszenia zdrowia Zygmunta III w dniu 26 kwietnia, jak i wyraźnie sterowana nieobecność jego najstarszego syna podczas przedpołudniowych ceremonii w dniu następnym sprawiają wrażenie świadomie rozegranych scen. Elekcyjny monarcha Rzeczypospolitej, zwłaszcza po rokoszu Zebrzydowskiego i wydanych wówczas konstytucjach sejmowych, nie mógł sobie pozwolić na ogłoszenie deklaracji dotyczącej ewentualnej sukcesji swego potomstwa ${ }^{44}$. Zygmunt III mógł uznać, że reguła ta nie odnosi się do momentu, w którym panujący władca na łożu śmierci ogłasza swą ostatnią wolę. Bunt czy sprzeciw senatorów lub szlachty byłby w tej sytuacji niestosowny i skazany na zderzenie z podniosłą i wzruszającą atmosferą królewskiego umierania. Być może 26 kwietnia, gdy król był niedostępny dla otoczenia, jego wola dotycząca potomstwa była dopiero opracowywana. Ze względu na stan zdrowia Zygmunta III mógł to być proces długotrwały i powolny, trudno określić, jak duży był w nim udział samego króla. Być może dyktował poszczególne zdania bądź konsultował tekst już opracowany. Rozpuszczenie fałszywych informacji dotyczących poprawy monarszego zdrowia byłoby w tym kontekście świadomą dezinformacją otoczenia, mającą na celu uwiarygodnienie decyzji podjętych przez króla. Skoro tego dnia król spacerował po pokoju, a nawet własnoręcznie podpisywał dokumenty, to naturalne było wnioskowanie, iż zdrowy i sprawny umysłowo monarcha podejmował

42 Relacyje nuncjuszów apostolskich i innych osób o Polsce od roku 1548 do 1690, t. 2, wyd. E. Rykaczewski, Berlin-Poznań 1864, s. 184.

43 W. Kaczorowski, op. cit., s. 51.

44 Warto zaznaczyć, że plany sukcesji były tematem poruszanym w schyłkowym okresie rządów Zygmunta III. Zob.: J. Seredyka, op. cit., s. 164, 206-207. 
świadome decyzje, których nie sposób było podważyć. Podobny mógł być cel wyprawy Władysława na łowy w okresie, gdy stan zdrowia jego ojca był krytyczny. Chodziło o to, by kandydat do sukcesji po ojcu nie był obecny przy ogłaszaniu jego deklaracji, odsuwając tym samym od siebie wszelkie możliwe zarzuty dotyczące wywierania wpływu na konającego monarchę. W grze o władzę kreowano w ten sposób sytuację fikcyjną: rządzący król był w pełni sił w przededniu ogłoszenia woli (to wzmacniało wiarygodność przekazu), nie wymieniał kandydata na swego następcę imiennie, podnosił raczej swoje zasługi i świetność dynastii Wazów (to raczej nie mogło przysporzyć Władysławowi wrogów na polu elekcyjnym), a główny kandydat na przyszłego elekta, królewicz Władysław, akurat polował poza Warszawą (wola ojca ogłoszona na łożu śmierci nie miała więc z nim bezpośrednio nic wspólnego, choć stanowiła wyraźną wskazówkę dla potencjalnych wyborców).

Kolejne dni życia Zygmunta III były przedłużającą się agonią. W nocy 27/28 kwietnia jego stan zdrowia pogorszył się, jednak następnego dnia był przytomny, a nawet komunikował się z otoczeniem za pomocą gestów. Czuwali przy nim na zmianę senatorowie oraz rodzina. 28 kwietnia około 21.00 odbyła się ceremonia pożegnania monarchy przez obecnych na dworze dostojników - zbliżali się oni do królewskiego łoża według hierarchii piastowanych godności, po czym całowali monarszą dłoń. 29 kwietnia nastąpiła tymczasowa poprawa: „W południe przekazał swe prawa do Królestwa Szwedzkiego królewiczowi Władysławowi; położył mu obie ręce na głowie i przeżegnał" ${ }^{45}$. Kanclerstwo w Szwecji oddał jednocześnie swemu kapelanowi Grzegorzowi Borastusowi ${ }^{46}$. Ceremonia ta została z czasem znacznie wyolbrzymiona - kronikarz Paweł Piasecki wspominał nawet, że umierający król własnoręcznie włożył na głowę syna koronę szwedzką, co wydaje się wątpliwe chociażby ze względu na jego stan zdrowia i wynikające stąd ograniczenia fizyczne ${ }^{47}$.

Przedłużająca się agonia oznaczała nie tylko cierpienie króla, ale generowała szereg problemów. Niechętni Zygmuntowi III opowiadali dowcipy

\footnotetext{
45 A. S. Radziwiłl, op. cit., s. 110.

46 Ibidem.

${ }^{47}$ Kronika Pawta Piaseckiego..., s. 354.
} 
o jego rogatej duszy, która nie chce opuścić ciała. W tym samym czasie, 29 kwietnia, Rada Senatu zajęła się zapewnieniem bezpieczeństwa stolicy w obliczu możliwości wybuchu zamieszek. W tym dniu wizytę władcy złożył nuncjusz apostolski Honorat Visconti, który modlił się przy nim, a także przekazał mu świecę przywiezioną z Loreto. Następnie została powtórzona ceremonia pożegnania Zygmunta III, tym razem w wersji rozszerzonej: „Wszystkich wtedy dopuszczono do ucałowania ręki królewskiej, i z miasta, i lokai, i hajduków, ludzi wszelkiego stanu i płci, tak że skóra na rękach króla pobielała od zbyt wielu pocałunków” ${ }^{48}$. W związku z krytycznym stanem monarchy noc na zamku spędzili niektórzy senatorowie, w tym: marszałek wielki koronny Łukasz Opaliński, K. Denhoff, podskarbi nadworny koronny J. M. Daniłowicz, podskarbi wielki litewski Stefan Pac. Oni też poinformowali pozostałych senatorów o ponownym ataku choroby. Wówczas liczba czuwających zwiększyła się, na zamek przybyli kolejni dostojnicy: kanclerz wielki koronny Jakub Zadzik, wojewoda łęczycki Stanisław Radziejowski, wojewoda smoleński Aleksander Gosiewski, kasztelan sieradzki Maksymilian Przerembski, A. S. Radziwiłł, Tomasz Zamoyski oraz podkanclerzy litewski Paweł Stefan Sapieha. Król zmarł 30 kwietnia 1632 roku około 3.00 nad ranem w obecności czuwających senatorów i księży śpiewających psalm „Błogosławieni niepokalani w drodze, którzy chodzą w zakonie Pańskim” ${ }^{49}$.

Majestatyczna oprawa śmierci Zygmunta III jest wielowymiarowa i zagadkowa. Ostatnie dni mogły być przez króla mistrzowsko rozegrane, zwłaszcza w kwestii rozdania wakansów, czy też tajemniczej nieobecności królewicza Władysława przy boku umierającego ojca. Być może mimo postępującej choroby Zygmunt III świadomie podejmował swe ostatnie decyzje. Królewska śmierć była w swym ziemskim wymiarze przepełniona

48 A. S. Radziwiłł, op. cit., s. 111.

49 Ibidem. Można przypuszczać, że wśród czuwających istniała pewna rotacja, np. A. S. Radziwiłł wspomina, że przybył na zamek „skoro tylko dał mi znać marszałek”, ale zastał już dwór opłakujący monarchę. Informacje o godzinie zgonu monarchy w: Relacyje nuncjuszów apostolskich..., t. 2, s. 184. Analogicznie BPAN, rkps 8403 (Teki Rzymskie t. 63), s. 205-207. Kwadrans przed trzecią podaje Relacyja o śmierci Ś.P. Zygmunta III króla polskiego d. 30 kwietnia R. 1632, [w:] Starożytności historyczne polskie, wyd. A. Grabowski, t. 1, Kraków 1840, s. 245. 
ludzkim cierpieniem, agonia monarchy trwała długo i musiała w obecnych budzić rozmaite refleksje na temat przemijania władców. W tym bardzo ludzkim procesie umierania starano się podkreślać wszelkie elementy majestatu króla: władca, choć złożony śmiertelną chorobą, odchodził w sposób godny, w otoczeniu dostojników i po dwukrotnej ceremonii pożegnania przez poddanych ${ }^{50}$.

\section{Jan III Sobieski}

Zdrowie Jana III Sobieskiego to temat znany i znakomicie opracowany m.in. dzięki studiom Witołda Ziembickiego oraz Karoliny Targosz ${ }^{51}$. Ten pierwszy, już kilkadziesiąt lat temu, analizował przypadłości monarchy, począwszy od najwcześniejszego okresu jego życia aż do momentu śmierci ${ }^{52}$. Wiadomo, że zwłaszcza w ostatnich latach życia stan zdrowia utrudniał Janowi III sprawowanie królewskich obowiązków. W 1693 roku choroba uniemożliwiła mu nawet udział w sejmie ${ }^{53}$. Z kolei historyk medycyny i lekarz, Stanisław Szpilczyński, poddał rewizji znane materiały dotyczące ostatnich lat życia króla oraz dokumentację sekcji zwłok, stwierdzając, że przyczyną jego śmierci nie była, jak dotychczas sądzono, mocznica nerek, lecz problemy z sercem ${ }^{54}$.

${ }^{50}$ Szczegółowe informacje na temat uroczystości żałobnych po śmierci Zygmunta III można znaleźć w: W. Kaczorowski, Koronacja Wtadystawa IV w roku 1633, Opole 1992, s. $11-13$.

${ }^{51}$ K. Targosz, Jan III Sobieski mecenasem nauk i uczonych, Wrocław-Warszawa-Kraków 1991, s. 241-244.

52 W. Ziembicki, Zdrowie i niezdrowie Jana Sobieskiego, cz. 1 „Archiwum Historii i Filozofii Medycyny oraz Historii Nauk Przyrodniczych” 1930, t. 10, s. 193-225; cz. 2, ibidem, 1931, t. 11, s. 26-45; cz. 3, ibidem, 1932, t. 12, s. 15-74. Szczegółowo o śmierci króla: L. Sługocki, Sekcja zwłok króla Jana III Sobieskiego, Łódź 2004 oraz idem, Zgon króla Jana III Sobieskiego. Ocena źródet, Łódź 2005.

53 W. Ziembicki, Wstrzymanie wyjazdu Jana III na sejm w grudniu 1693, „Kwartalnik Historyczny" 1933, R. 47, s. 576-580.

54 S. Szpilczyński, Najprawdopodobniejsza przyczyna zgonu Jana III Sobieskiego „Śląski Kwartalnik Historyczny Sobótka” 1980, t. 35, nr 2, s. 329-336. 
Ostatnie miesiące życia monarchy to stopniowe pogarszanie się jego stanu zdrowia, na przemian z przejściowymi poprawami. Król cierpiał z powodu duszności, z tego też względu spędzał noce w pozycji siedzącej otulony futrami ${ }^{55}$. W kwietniu 1696 roku 9 lub 10 razy podano mu preparat rtęciowy, który przyniósł chwilową poprawę, w połowie maja król bawił nawet na polowaniu. Zwołane consilium lekarskie zaleciło Janowi III ciepłe kąpiele mineralne; po licznych debatach, a nawet po zasięgnięciu opinii Rady Senatu, zdecydowano o wyjeździe króla do Wiesbaden (Aix-la-Chapelle), który miał nastąpić w bliżej nieokreślonym terminie ${ }^{56}$. Ostatecznie podróż ta nigdy nie została zrealizowana, podobnie jak poprzedzająca ją planowana wyprawa do Żółkwi. Finalny etap życia króla, interesujący z punktu widzenia majestatycznej oprawy jego śmierci, trwał zaledwie trzy dni, od 15 do 17 czerwca 1696 roku. Sceną owych wydarzeń był Zamek Wilanowski, ulubiona rezydencja Jana III i jego małżonki.

O pierwszych dniach choroby Jana III, niestety, niewiele wiadomo. Po przejażdżce, która odbyła się w piątek 15 czerwca, król znacznie osłabł. Cierpiał zarazem z powodu uciążliwego kaszlu, który uniemożliwiał mu sen podczas piątkowej i sobotniej nocy ${ }^{57}$. Już wówczas pojawiły się inne niepokojące symptomy: „gdy się z tej przejażdżki powrócił i był do pokoju wprowadzony, zdało mu się, że nie do swego wchodził pokoju, co po sobie znacznie był pokazał"58. Po tym niepokojącym zdarzeniu król nieco doszedł do siebie, odzyskał też trzeźwość umysłu. W niedzielę 17 czerwca przed południem monarcha sporo czasu spędził w wilanowskich ogrodach. Kazał się tam zanieść pomiędzy 8.00 a 9.00 rano. Siedział na specjalnie skonstruowanym krześle, umożliwiającym przenoszenie z miejsca na miejsce. W ogrodach, mimo panującego wiatru, Jan III spożył też polewkę ${ }^{59}$. Wczesnym popołudniem monarcha zauważył niepokojący objaw - nie czuł

55 W. Ziembicki, Zdrowie i niezdrowie..., cz. 1, s. 215.

56 Ibidem, s. 216.

57 W. Ziembicki, Nieznana relacja o śmierci Jana III, „Kwartalnik Historyczny”, R. 47, (1933), s. 215 (K. Sarnecki do K. S. Radziwiłła, Warszawa, 20 VI 1696)

58 Relacyja o skończeniu żywota króla Jana III, „Tygodnik Powszechny”, R. 1884, 12, s. 186. Jest to relacja spisana przez spowiednika królewskiego ks. A. Skopowskiego.

59 Ibidem. S. Szpilczyński podaje informację, że król jadł tego dnia w zamkowych wnętrzach. Idem, op.cit., s. 333. 
zapachów kwiatów i krzewów. Został więc natychmiast przetransportowany do zamkowych wnętrz, gdzie spędził popołudnie, wysłuchując mszy świętej (lekarze zabronili my wyruszać w tym stanie do kościoła) oraz odprawiając zwyczajowe modlitwy. Następnie rozmawiał z królową Marysieńką, posłem francuskim Melchiorem de Polignac oraz biskupem płockim Jędrzejem Załuskim $^{60}$. Monarcha, wbrew sugestiom tego ostatniego, odmawiał wyspowiadania, tłumacząc się brakiem przygotowania oraz nieodległym posiłkiem (pomiędzy godzinami 15.00 a 16.00, zgodnie z jego wyraźnym życzeniem, książę Aleksander podał mu wino ${ }^{61}$ ). Królewski spowiednik, ks. Ambroży Skopowski, zauważył, iż król w miarę upływu popołudniowych godzin, spożywania wina oraz debatowania z królową i ambasadorem francuskim stawał się coraz słabszy. Nawet jeśli był to wniosek skonstruowany post factum, to niewątpliwe jest, że po południu w Warszawie zaczęto odprawiać nabożeństwa za zdrowie Jana III, związane z wiadomościami o chorobie oraz nieodległą 23. rocznicą jego elekcji ${ }^{62}$.

Od przeniesienia króla do zamku do wyraźnego pogorszenia jego stanu upłynęło kilka godzin. Około 18.00 monarcha spadł z dziennego łóżka (zapewne chodziło o rodzaj szezlongu). Powodem był pierwszy atak konwulsji. Zgromadzeni medycy uważali, że „się już była przybliżyła puchlina do serca"63. Wezwany ksiądz, zapewne A. Skopowski, udzielił ostatniego namaszczenia, choć kilka godzin później to biskup J. Załuski utrzymywał,

${ }^{60}$ Zbiór pamiętników o dawnej Polszcze (dalej jako: Zbiór pamiętników), wyd. J.U. Niemcewicz, Lipsk 1839, t. 4, s. 333-334, O ostatnich chwilach króla Jana III rzecz wyjęta z pamiętników Zatuskiego [...]. Jest to tłumaczenie fragmentu relacji znajdującej się w: A.C. Załuski, Epistolae historico-familiares, Braniewo 1711, t. 2, s. 12-16.

${ }^{61}$ Relacyja o skończeniu..., s. 186.

${ }^{62}$ Zbiór pamiętników, t. 4, s. 335, J. Załuski do M. Radziejowskiego (i innych), 17 VI 1696. Informacja o wzmiankowanej rocznicy często pojawia się w źródłach, choć elekcja Jana III odbyła się 21 maja 1674 r. Miała ona jednak miejsce w dzień po święcie Zesłania Ducha Świętego, które w roku śmierci króla przypadało właśnie 17 czerwca. Sprawa była niejasna już dla współczesnych, skoro pijar ks. Piotr pisał, że Jan III nie doczekał rocznicy swego wyboru, która przypadała 19 czerwca (sic!). Zob. Biblioteka Książąt Czartoryskich w Krakowie (dalej jako: B.Czart), rkps 2085, nr 6, ks. Piotr do E. Sieniawskiej (?), Warszawa, 20 VI 1696.

${ }^{63}$ Nieznana relacja..., s. 214-215, K. Sarnecki do K. S. Radziwiłła, Warszawa, 18 VI 1696. 
że sam udzielił monarsze rozgrzeszenia in articulo mortis. Podobno król dał znak, że prosi o rozgrzeszenie, ściskając jego rękę ${ }^{64}$.

Prawdopodobnie wszyscy zgromadzeni w Pałacu Wilanowskim zdawali sobie sprawę z powagi sytuacji. Króla otaczała rodzina, dostojnicy świeccy oraz duchowni. Najbliższych reprezentowali Aleksander i Konstanty Sobiescy (Jakub rezydował wówczas w Marywilu) oraz królowa Marysieńka, która wyczerpana dotychczasową opieką nad mężem, część czasu spędziła w swoich apartamentach. Wśród dostojników, którzy najwcześniej byli w Wilanowie, znajdowali się: sekretarz wielki koronny Mikołaj Wyżycki, generał wielkopolski Rafał Leszczyński, poseł francuski Melchior de Polignac oraz marszałek wielki koronny Stanisław Lubomirski. Do momentu śmierci Jana III dodatkowo przybyli biskupi: poznański Stanisław Witwicki, płocki Jędrzej Załuski, inflancki Mikołaj Popławski, oraz senatorowie: marszałek nadworny koronny Aleksander Sapieha, podskarbi koronny Hieronim Lubomirski, kasztelan sądecki Michał Szwarcenberg Czerny, podstoli koronny Jerzy Dominik Lubomirski i podskarbi nadworny koronny Atanazy Miączyński. Obecni byli również księża Jan Władysław Przerembski oraz Aleksander Wyhowski ${ }^{65}$. Źródła nie pozwalają na określenie, w jakiej kolejności przybywali oni do Wilanowa i przez kogo byli zawiadamiani. Można jedynie przypuszczać, że początkowo króla otaczali nieliczni dostojnicy (wymienieni przez K. Sarneckiego w pierwszej kolejności - od M. Wyżyckiego po S. Lubomirskiego). Grono to stopniowo było uzupełniane o kolejnych senatorów. Już przed samą śmiercią króla pojawili się biskupi S. Witwicki i M. Popławski. Na miejscu znajdowali się również dworzanie wilanowscy - „zaledwie który trzeźwy”66.

${ }^{64}$ Zbiór pamiętników, t. 4, s. 335, J. Załuski do M. Radziejowskiego (i innych), 17 VI 1696. Relację Załuskiego potwierdza opis autorstwa ks. A. Skopowskiego - było to odpuszczenie grzechów w obliczu śmierci, a nie ostatnie namaszczenie (decydowała o tym zapewne nagłość zaistniałej sytuacji). Zob.: Relacyja o skończeniu..., s. 186.

${ }^{65}$ Nieznana relacja..., s. 216-217, K. Sarnecki do K. S. Radziwiłła, Warszawa, 20 VI 1696.

${ }^{66}$ Zbiór pamiętników, t. 4, s. 335, J. Załuski do M. Radziejowskiego (i innych), 17 VI 1696. Detaliczna analiza tożsamości obecnych przy zgonie króla w: L. Sługocki, Zgon króla..., s. 87-103. 
Agonia monarchy rozpoczęła się 17 czerwca około godziny 18 (niektóre źródła podają $16.00-16.30{ }^{67}$. Ocucono go, aplikując emetyk oraz środki purgujące, które przyniosły chwilową poprawę. Monarsze podano również komunię świętą, uczynili to wspólnie biskup J. Załuski oraz spowiednik króla, ks. Skopowski ${ }^{68}$. Zabiegi przy ratowaniu królewskiego życia przez lekarzy trwały prawie godzinę i miały dramatyczny przebieg, zwłaszcza że były przeprowadzane przy udziale rodziny królewskiej i zgromadzonych dostojników. Stąd lamenty i modlitwy, które dawały się słyszeć w tle. Obawiając się zmiany pozycji króla pozostawiono go leżącego na podłodze, a by zapobiec wyziębieniu obkładano go ciepłymi serwetami ${ }^{69}$. O oprawie śmierci decydowały w tym wypadku względy medyczne i praktyczne. Dopiero po godzinie, czyli ok. 19.00, król został podniesiony na łóżko, ciągle jednak nie dostrzegano szczególnej poprawy jego stanu. Ta ostatnia, choć chwilowa, pojawiła się po kolejnych 2 godzinach: „[król] znowu revivixit, rycząc jak wół”70. Według innej relacji „kichnąwszy mocno do siebie przyszedł"71.

Król znowu mógł rozmawiać z obecnymi dostojnikami, jednak dialogi te nie dotyczyły spraw państwowych. Sekretarz M. Wyżycki relacjonował smutek senatorów spowodowany jego chorobą, a generał wielkopolski i poseł francuski sprawdzali siłę królewskiego uścisku. Jan III ponownie wydawał się pozostawać w niezłej formie - podobno „na doktorów łajał, na chłopca się zamierzył”, wyspowiadał się, ale nie zdołał przyjąć komunii

${ }^{67}$ Tron pamiątek ku czci „Najjaśniejszego, Niezwyciężonego Jana III Sobieskiego Króla Polskiego" w trzechsetlecie śmierci: 1696-1996 [Katalog wystawy], Warszawa 1996, s. 194.

${ }^{68}$ Zbiór pamiętników, t. 4, s. 336, J. Załuski do M. Radziejowskiego (i innych), 17 VI 1696. Ks. A. Skopowski wspomina o namaszczeniu olejami i o podaniu następnie fragmentu Agnus Dei Innocentego XI. Relacyja o skończeniu..., s. 187.

69 Tron pamiatek ku czci..., s. 194.

70 Nieznana relacja..., s. 216, K. Sarnecki do K. S. Radziwiłła, Warszawa, 20 czerwca 1696.

${ }^{71}$ B. Czart, rkps 2085, nr 6, ks. Piotr do E. Sieniawskiej (?), Warszawa, 20 VI 1696. Pamfletem jest zapewne relacja przekazana rzekomo przez kardynała Melchiora de Polignac i zamieszczona w zbiorze Le spicilège de Montesquieu, wyd. A. Masson, Paryż 1944, a następnie bezkrytycznie przywołana przez L. Sługockiego, Zgon króla..., s. 57-58. 
świętej ${ }^{72}$. Jego ostatnie chwile były całkowicie wolne od polityki. Z relacji Kazimierza Sarneckiego wynika, że rozdanie przez króla wakansów było w tej sytuacji niemożliwe, gdyż „niesłychanie ciężki Pan był przed tą śmiercią do podpisu"73. Spraw nierozstrzygniętych pozostało sporo, co wynikało zapewne z przekonania samego Jana III, że jego wola nie była szanowana za życia, więc analogicznie będzie po śmierci. Zarówno w ostatnich chwilach życia monarchy, jak i w trakcie kilku poprzednich miesięcy nie było mowy o debatowaniu przy królu o jakichkolwiek planach elekcyjnych. Jan III nie zdecydował się nawet na spisanie testamentu, do czego kilka tygodni przed śmiercią namawiał go biskup J. Załuski ${ }^{74}$. Przed śmiercią król zwrócił się do obecnych przy nim synów, Aleksandra i Konstantego, by swą matkę „kochali i szanowali"75.

Poprawa królewskiego stanu trwała zapewne od jednej do dwóch godzin. Na godzinę przed śmiercią monarcha miał drugi atak paroksyzmu. Otrzymał rozgrzeszenie i ostatnie namaszczenie od jednego z biskupów S. Witwickiego bądź M. Popławskiego ${ }^{76}$, po czym zmarł „z ciężkim krzykiem”77 około godziny 22.00. Według innej relacji „stękając powoli P. Bogu ducha oddał"78. J. Załuski wspomina o zgonie między 20.00 a 21.00, jednak biorąc pod uwagę chronologię ostatnich chwil życia Jana III, ta pierw-

72 Nieznana relacja..., s. 216-216, K. Sarnecki do K. S. Radziwiłła, Warszawa, 20 czerwca 1696. Zbiór pamiętników, t. 4, s. 336, J. Załuski do M. Radziejowskiego (i innych), 17 VI 1696. Króla spowiadał przez trzy kwadranse ks. A. Skopowski. Co ciekawe, z jego relacji wynika, że król po spowiedzi przyjął komunię świętą. Rozbieżności są spore, bardziej wiarygodny wydaje się jednak pełen detali opis J. Załuskiego.

${ }^{73}$ Nieznana relacja..., s. 219, K. Sarnecki do K.S. Radziwiłła, Warszawa, 18 VI 1696.

${ }^{74}$ Zbiór pamiętników, t. 4, s. 333-334.

${ }^{75}$ Cyt. za: M. Komaszyński, Królowa Maria Kazimiera, Warszawa 1992, s. 71. Relacya księdza Skopowskiego o ostatnich chwilach Jana III, [w:] E. Łuniński, Wspominki. $Z$ dni historycznych kart kilka z ilustracyami, Warszawa 1910, s. 346.

${ }^{76}$ Zbiór pamiętników, t. 4, s. 336, J. Załuski do M. Radziejowskiego (i innych), 17 VI 1696.

${ }^{77}$ Nieznana relacja..., s. 215, K. Sarnecki do K.S. Radziwiłła, Warszawa, 18 VI 1696. Według królewskiego spowiednika śmierć była „bez żadnej ciężkości” (znaczna rozbieżność w opisach, raczej na niekorzyść wiarygodności relacji ks. Skopowskiego).

${ }^{78}$ B.Czart, rkps 2085, nr 6, ks. Piotr do E. Sieniawskiej (?), Warszawa, 20 VI 1696. 
sza wersja wydaje się bardziej prawdopodobna, zwłaszcza że jeszcze pół godziny przed 22.00 wysłano do warszawskich klasztorów prośby o modlitwy za króla w związku z pogorszeniem stanu jego zdrowia ${ }^{79}$.

Ciało monarchy „zaraz nocą z Wilanowa” wyprowadzono, przy czym dla współczesnych było jasne, że była to ceremonia o charakterze prywatnym $^{80}$. Około 3.00 w nocy zwłoki już były na Zamku Warszawskim. Po dramatycznej scenie przy wjeździe na zamek, w której uczestniczyli: królowa, Jakub Sobieski i biskup J. Załuski, tymczasowo złożono je w komnatach fraucymeru, natychmiast przystępując do przygotowania ich odpowiedniej oprawy ${ }^{81}$. Wszystko to odbywało się $\mathrm{w}$ wyraźnym pośpiechu, zgodnie z przekonaniem, że to Zamek Królewski, oficjalna rezydencja monarchy, stanowi odpowiednie decorum dla wszelkich funeralnych uroczystości ${ }^{82}$. Wynikało to z jego oficjalnego charakteru jako rezydencji monarszej - nawet jeśli zgon króla miał jak najbardziej ludzki aspekt, to natychmiast po śmierci wracano do celebrowania iście królewskiego majestatu, którego częścią były egzekwie, przygotowanie do pogrzebu, a wreszcie sama ceremonia pożegnania ${ }^{83}$. Niezwłoczne przeniesienie ciała na Zamek Królewski odbywało się już kilkakrotnie w wypadku śmierci członków królewskich rodzin ${ }^{84}$.

79 Zbiór pamiętników, t. 4, s. 336, J. Załuski do M. Radziejowskiego (i innych), 17 VI 1696. Informacja o zgonie „przed dziesiątą” i o wysłaniu kartek do klasztorów w: B.Czart, rkps 2085, nr 6, ks. Piotr do E. Sieniawskiej (?), Warszawa, 20 VI 1696.

${ }^{80}$ Nieznana relacja..., s. 215, K. Sarnecki do K.S. Radziwiłła, Warszawa, 18 VI 1696; B.Czart, rkps 2085, nr 6, ks. Piotr do E. Sieniawskiej (?), Warszawa, 20 VI 1696.

${ }^{81}$ M. Komaszyński, op. cit., s. 73; idem, Maria Kazimiera d'Arquien królowa Polski 1641-1716, Kraków 1983, s. 175-177; J. Lileyko, Zamek warszawski. Rezydencja królewska i siedziba wtadz Rzeczypospolitej 1569-1763, Wrocław 1984, s. 159, 177.

${ }^{82}$ Zamek Królewski został zamknięty już po pierwszym ataku konwulsji króla z inicjatywy królewicza Jakuba. Zapieczętowano również skarbiec królewski w obecności podskarbiego koronnego Hieronima Augustyna Lubomirskiego. B.Czart, rkps 2085, nr 6, ks. Piotr do E. Sieniawskiej (?), Warszawa, 20 VI 1696.

${ }^{83}$ J. Lileyko, op. cit., s. 270-275.

${ }^{84} \mathrm{~W}$ ten sposób, również pod osłoną nocy, 9 sierpnia 1647 r. transportowano na Zamek Królewski ciało syna Władysława IV, Zygmunta Kazimierza, który zmarł w Pałacu Ogrodowym przy Krakowskim Przedmieściu. Analogicznie przewożono ciało królowej Ludwiki Marii. Zob.: B. Fabiani, op. cit., s. 71 (na podstawie relacji S. Oświęcima), s. 202. 
Król Jan III Sobieski chorował na tyle ciężko i długo, by przyzwyczaić poddanych do zaistniałego stanu ${ }^{85}$. Jego śmierć, choć nagła, nie była dla nikogo zaskoczeniem. Królewskie niedomagania splatały się przez lata z koniecznością wykonywania monarszych obowiązków, a pod koniec życia niejednokrotnie je ograniczały bądź uniemożliwiały. Owo cierpienie królewskie już przez współczesnych było sakralizowane - biskup J. Załuski przekonywał Jana III kilka tygodni przed śmiercią „znoś ciała boleści; tysiąc ofiar u ołtarzów Pańskich podnosi się na co dzień za całość twoją" ${ }^{36}$. Również on utrzymywał, że poprawa zdrowia króla 17 czerwca nastąpiła w wyniku podania mu komunii św., a dzień monarszej śmierci wypadł nieprzypadkowo w Święto Zesłania Ducha Świętego ${ }^{87}$. Obraz ten uzupełniał spowiednik królewski, ks. A. Skopowski, zapewne chcąc przekonać odbiorców, iż król dopełnił wszystkich obrzędów religijnych niezbędnych do bycia zbawionym. W jednej z zachowanych wersji swej relacji zaznaczył, że Jan III po spowiedzi zdązył przyjąć komunię św., choć pozostałe źródła wskazują, iż to nie nastąpiło. Król nie tylko nie był na czczo, ale i zaistniały problemy ze znalezieniem miejscowego proboszcza, który mógłby otworzyć kościół ${ }^{88}$.

Sama królewska agonia była bardziej ludzka niż majestatyczna "monarcha tak bogaty na ziemi umieraf" ${ }^{99}$ - o wyjątkowej randze Jana III przypominali jedynie senatorowie obecni w Pałacu Wilanowskim. Nawet miejsce, w którym monarcha zmarł, nie wydawało się współczesnym na tyle godne, by zrezygnować $\mathrm{z}$ natychmiastowego transportu jego ciała na

${ }^{85}$ Filip Dupont podkreślał, że król w dniu śmierci jeszcze spacerował i był aktywny w typowy dla siebie sposób. Idem, Mémoires pour servir à l'histoire de la vie et des actions de Jean Sobieski III, [w:] Biblioteka Ordynacyi Krasińskich. Muzeum Konstantego Świdzińskiego, t. 8, wyd. J. Janicki, Warszawa 1885, s. 234.

${ }^{86}$ Zbiór pamiętników, t. 4, s. 333.

${ }^{87}$ Ibidem, s. 336, J. Załuski do M. Radziejowskiego (i innych), 17 VI 1696.

${ }^{88}$ Relacyja o skończeniu..., s. 187. Por.: J. Załuski oraz K. Sarnecki. Z relacji ks. Skopowskiego wynika, że przyjęcie komunii nastąpiło bezpośrednio po spowiedzi, czyli na osobności. Może więc fakt ten umknął uwadze J. Załuskiego i K. Sarneckiego? Co ciekawe, w drugiej z zachowanych wersji relacji spowiednika, zaznaczono, że Jan III nie przyją komunii świętej. Zob.: Relacya księdza Skopowskiego..., s. 343. Przyjmowano również, że król komunię przyjął, ale „deficiente sensu”. Zob.: L. Sługocki, Zgon króla..., s. 74.

${ }^{89}$ Dzieje Jana III, króla Polskiego, Wielkiego Księcia Litewskiego, opr. L. Rogalski, Warszawa 1847, s. 413. 
Zamek Królewski, ściśle związany z urzędem i majestatem króla. W tym bardzo ludzkim umieraniu Jana III warto zwrócić uwagę na pieczołowitość w dążeniu do zrealizowania wszelkich obrzędów religijnych, które miały zapewnić człowiekowi, również monarsze, zbawienie. One też zdominowały obraz ostatnich chwil życia króla.

\section{August II Sas}

August II Sas, podobnie jak Jan III Sobieski, zdołał przyzwyczaić poddanych do cyklicznie pogarszającego się stanu zdrowia. Królewska choroba stawała się parokrotnie nawet przedwczesnym pretekstem do wszczęcia elekcyjnych targów na zagranicznych dworach ${ }^{90}$. Drastyczny opis ostatnich dni Wettyna Szymon Askenazy mistrzowsko wplótł w relację o jego fatalnym panowaniu w Rzeczypospolitej ${ }^{91}$.

August II po raz ostatni przybył na sejm nadzwyczajny do Warszawy w piątek 16 stycznia 1733 roku „głębokim wieczorem”, zapewne około godziny $19.00^{92}$. Już w momencie dotarcia do stolicy monarcha był poważnie chory, jego kareta podjechała od tyłu do Pałacu Saskiego. Monarcha został wniesiony do pałacowych wnętrz przez pachołków, a następnie przetransportowany prosto do łóżka. Scena ta miała pozostać niewidoczna dla widzów ${ }^{93}$. Nazajutrz, 17 stycznia, stan zdrowia króla pozwalał na przyjęcie

${ }^{90}$ J. Staszewski, Traktatu Loewenwolda nie byto!, [w:] idem, "Jak Polskę przemienić w kraj kwitnacy..." Szkice i studia z czasów saskich, Olsztyn 1997, s. 134. Problemem króla była odnawiająca się rana na nodze. Zob. m.in. Archiwum Narodowe w Krakowie, Archiwum Sanguszków, teka 422/11, s. 1-4, A. Cichocki do J. Dunina, Warszawa, 4 IX 1728.

91 S. Askenazy, Z dziejów ostatniego bezkrólewia, [w:] idem, Dwa stulecia XVIII i XIX, Warszawa 1901, s. 56-57. Zły stan zdrowia Augusta II Askenazy łączył z suto zakrapianym spotkaniem króla z pruskim ministrem Wilhelmem Grumbkowem. Przebieg tego spotkania został zakwestionowany w: J. Staszewski, Ostatni „wielki plan” Augusta Mocnego, [w:] idem, op. cit., s. 117-133.

92 „Kurier Polski” 1733, nr 161. Królowi towarzyszyli H. Brühl oraz marszałek i koniuszy nadworny J. G. Einsidel.

${ }_{93}$ B.Czart, rkps MNK 32, s. 1, Sejm ekstraordynaryjny dwuniedzielny, na którym król August 2. umart w Warszawie R.P. 1733. Informacje na ten temat również w: J. Kurek, 
nielicznych gości, z których najważniejszy był marszałek wielki koronny Józef Mniszech. Oceniał on formę władcy niezbyt optymistycznie, zaznaczając jednak, że August II starał się nie pokazywać słabości, rozmawiając z nim „rzeźwo" "94. Tego samego dnia po południu monarcha przyjmował podkanclerzego koronnego i biskupa nominata krakowskiego Jana A. Lipskiego. 18 stycznia liczba odwiedzających w Pałacu Saskim znacząco wzrosła, a król udzielił kilku audiencji prywatnych, głównie przybyłym ministrom. Wstępnie planowano w tym dniu jego przetransportowanie na Zamek Królewski, jednak zgromadzeni lekarze nie pozwolili na to ze względu na stan zdrowia władcy.

Gdy 26 stycznia 1733 roku rozpoczynały się obrady sejmu nadzwyczajnego, stan zdrowia króla był na tyle poważny, że nie mógł wziąć udziału w wotywie „lubo wielką miał chęć” ${ }^{95}$. W zaistniałej sytuacji publiczna aktywność króla musiała zostać znacząco ograniczona. Po inauguracji obrad sejmowych i opuszczeniu przez posłów Senatu, senatorowie oraz ministrowie udali się do Pałacu Saskiego. Monarcha spoczywał na łożu, w związku z czym rozmowę z nim odbył tylko marszałek J. Mniszech. We wtorek 27 stycznia August II nie przyjmował gości, wyjątek uczynił dla chorążego koronnego Jana Klemensa Branickiego ${ }^{96}$. S. Askenazy napisał o tych dniach: „Nie dopuszczał do siebie nikogo oprócz lekarzy i służby”97, co miało - w intencji autora - odpowiednio udramatyzować podejmowane przez Czartoryskich starania dotarcia do króla i skłonienia go do zatwierdzenia wakansów. Mieli oni nawet przekupić kamerdynera królewskiego, ofiarując mu parę tysięcy dukatów za umożliwienie dostępu do umierającego Augusta II ${ }^{98}$.

Trwające obrady sejmowe wymuszały na monarsze minimalne angażowanie się w związane z nimi procedury. 28 stycznia w środę król, siedząc

U schytku panowania Augusta II Sasa. Z dziejów wewnętrznych Rzeczypospolitej (1729-1733), Katowice 2003, s. 131.

${ }^{94}$ B.Czart, rkps MNK 32, s. 1, Sejm ekstraordynaryjny dwuniedzielny...

95 Ibidem.

${ }^{96}$ Ibidem, s. 2.

${ }^{97}$ S. Askenazy, op. cit., s. 57.

${ }^{98}$ Ibidem. Podobnie E. Rostworowski, O polska koronę. Polityka Francji w latach 1725-1733, Wrocław 1953, s. 318. 
na swym obrotowym krzesełku, przyjął delegację szlachecką. Towarzyszył mu marszałek J. Mniszech. Delegaci poinformowali władcę o wybranym marszałku sejmowym. Stan zdrowia Augusta II raczej napawał ich optymizmem $^{99}$, a atmosfera spotkania była $\mathrm{w}$ ich opinii dobrym prognostykiem dla trwającego właśnie sejmu ${ }^{100}$. Nastrój ten nie trwał długo - w czwartek, piątek i sobotę po Warszawie krążyły już informacje o krytycznym stanie zdrowia króla ${ }^{101}$. 30 stycznia w piątek jego stan był na tyle poważny, że w Pałacu Saskim została podjęta decyzja o posłaniu po spowiednika, misjonarza, ojca St.-Germain. Ok. 14.00 udał się po niego konsyliarz saski Johann Anton Thioly. Ojciec St.-Germain był nieco zaskoczony powierzoną mu rolą, jednak bezzwłocznie udał się do pałacu. Odczekawszy chwilę w antykamerze, został dopuszczony przed oblicze króla, który co prawda cierpiał z powodu utrzymującego się bólu, jednak pozostawał w pełni władz umysłowych ${ }^{102}$. Wszystkie osoby obecne w królewskiej komnacie (brak jakichkolwiek szczegółów!) musiały ją opuścić, a August II rozpoczął swą spowiedź. Monarcha, jak wynika z relacji spowiednika, nie czuł jeszcze śmiertelnego niebezpieczeństwa, poddawał się jednak „woli i dyspozycyi Boskiej" ${ }^{103}$. Siły nie pozwalały mu na odbycie spowiedzi generalnej (byłaby ona już czwartą w życiu władcy), a samo wyznanie grzechów nastąpiło z pewną pomocą i zachętą ze strony spowiednika. Padło wówczas wyznanie:

99 B.Czart, rkps MNK 32, s. 2, Sejm ekstraordynaryjny dwuniedzielny...; „Kurier Polski” 1733, nr 163; „zastali J.K.Mci oko i ucho wesołe, otwarte serce ku dobru pospolitemu, a lubo w nadsłabiałym zdrowiu, ale fortem animi confirmationem do zgodnej harmonij i utrzymania dalszych obrad publicznych".

100 B.Czart, rkps MNK 32, s. 20, Diariusz sejmu dwuniedzielnego ekstraordynaryjnego $w$ Warszawie die 26 Januarii 1733 zaczętego.

101 Ibidem, s. 2, Sejm ekstraordynaryjny dwuniedzielny...

102 Ibidem, s. 3, Relacyja śmierci nieśmiertelnej. Pamięci króla Jmci Augusta 2. Die Ima Februarii A. 1733 w Warszawie zmartego podczas sejmu ekstraordynaryjnego dwuniedzielnego spisana ręka wtasna po francusku d'M.L. Abbé St. Ger Main [!], który króla Jmci in viam aeternitatis dysponowat genuine po polsku przettumaczona. Inne egzemplarze: B.Czart, rkps 853 IV, s. 219-221 (wersja zatytułowana Post obitum Serenissimi Regis Augusti die 2 Februarii hora Gta de mare stante interregni ejusdum notanda, nieco skrócona w porównaniu do pozostałych); Biblioteka Zakładu Narodowego im. Ossolińskich we Wrocławiu (dalej: B.Oss), rkps 302 II, s. 1-5; B.Oss, rkps 3577 II, k. 1-4.

${ }^{103}$ B.Czart, rkps MNK 32, s. 3, Relacyja śmierci nieśmiertelnej... 
„nigdy nie myślił Polszcze szkodzić, owszem się zawsze o Dobro Pospolite i utrzymanie w niej pokoju starał" ${ }^{104}$. Rozmowa i spowiedź trwały ok. 2 godzin. Ze względu na dość dobry stan fizyczny króla ojciec St.-Germain zrezygnował w tym momencie z szafowania komunii św. i ostatniego namaszczenia. Miały być one udzielone nazajutrz, jednak spowiednik nie zdecydował się na opuszczenie Pałacu Saskiego. Gdy przed godziną 23.00 okazało się, że stan zdrowia króla znacząco się pogorszył, co ogłosił dworzanin Henryk Brühl po wizycie w jego komnatach, natychmiast posłano po sakramenty do kościoła Świętego Krzyża. Ojciec St.-Germain dopilnował, by wszystkie ceremonie związane ze zbawieniem królewskiej duszy zostały dopełnione, w tym ostatnie namaszczenie, akty wiary, deklaracja, że monarcha odpuszcza nieprzyjaciołom i prosi o odpuszczenie win, a wreszcie komunia święta, którą król przyjął z rąk misjonarza ks. Baudouina. Ceremonie te zakończyły się około $2.00 \mathrm{w}$ nocy ${ }^{105}$.

Dnia 31 stycznia w sobotę ojciec St.-Germain nie opuścił pałacu, towarzysząc Augustowi II aż do północy. Monarcha był nieco spokojniejszy, spożył też spory posiłek. W źródłach nie znajdują potwierdzenia informacje podawane m.in. przez $S$. Askenazego o wyjątkowo bolesnym i pełnym cierpienia końcu jego ziemskiej drogi, którą miało zakończyć słynne zdanie „całe moje życie było jednym nieprzerwanym grzechem” oraz porównanie polskiej korony do cierniowej ${ }^{106}$. W rzeczywistości królewska agonia rozpoczęła się w nocy z soboty na niedzielę (31 stycznia/1 lutego) ok. 5.00 nad ranem, gdy August II utracił zdolność rozumienia i komunikowania się z otoczeniem. W ostatnich chwilach towarzyszyły mu modlitwy. 1 lutego w niedzielę rano Henryk Brühl poinformował marszałka J. Mniszcha o krytycznej sytuacji ${ }^{107}$. Ten udał się do kościoła św. Jana oraz wysłał wieści do pozostałych ministrów. Otrzymawszy wiadomość, że król „agoniza-

104 Ibidem, s. 4.

105 Ibidem, s. 4-5.

106 S. Askenazy, op. cit., s. 57, 61. Prawdziwość tego zdania dość ostrożnie poddał w wątpliwość J. Staszewski, August II Mocny, Wrocław 1998, s. 276.

107 B.Czart, rkps MNK 32, s. 5, Relacyja śmierci nieśmiertelnej... „W niedzielę zaś $1 \mathrm{ma}$ Februarii o piątej z rana dano mi znać, że król Jmć bardzo się źle ma i konać zaczyna”. 
t"108, natychmiast wyruszył do Pałacu Saskiego, ale nie zastał już Augusta II żywego. O 9.00 ojciec St.-Germain odprawił mszę św. w pierwszym pokoju apartamentów królewskich. Byli na niej obecni zarówno marszałek J. Mniszech, jak i podkanclerzy J. A. Lipski. Spowiednik przekazał zarazem ostatnią wolę Augusta II, który polecał całą swą służbę synowi oraz prosił go o uczynienie pobożnej fundacji na rzecz ubogich. Ojciec St.-Germain zapewnił zgromadzonych, że król zmarł pogodzony z Bogiem i w pobożny sposób $^{109}$. Zapewne po zakończeniu tych ceremonii marszałek J. Mniszech udał się do prymasa Teodora Potockiego, by oficjalnie poinformować go o śmierci króla.

Ciało 1 i 2 lutego spoczywało w Pałacu Saskim. Tu też postawiono warty ${ }^{110}$. Dopiero 2 lutego ok. godziny 22.00 z inicjatywy marszałka J. Mniszcha zostało przeniesione na Zamek Królewski, przy czym ceremonia ta miała prywatny charakter ${ }^{111}$. Brak pośpiechu w transportowaniu królewskiego ciała do oficjalnej rezydencji jest nader zagadkowy, zwłaszcza w zestawieniu z niecierpliwością okazywaną w tym względzie przez uczestników śmierci Jana III Sobieskiego w 1696 roku. Być może chodziło o jak najdłuższe zachowanie tajemnicy, władca przecież zmarł w nadzwyczajnych okolicznościach, bo w trakcie sejmu ${ }^{112}$. Dopiero po złożeniu ciała Augusta II na Zamku Królewskim, 3 lutego, zakończono obrady sejmu, a posłowie "wizytowali de mortuum cadaver" 113 . Pożegnanie to miało prywatny charakter, gdyż ciało nie było jeszcze przygotowane do publicznego okazania.

Śmierć Augusta II, choć długa i bolesna, nie obfitowała w zbyt wiele teatralnych momentów. Do takowych można zaliczyć jedynie wizytę delegacji sejmowej przyjętej przez króla siedzącego na swym obrotowym krzesełku. Monarcha przybył do Warszawy pod osłoną nocy i do końca swych dni miał dość iluzoryczny kontakt nawet z najważniejszymi polski-

108 Ibidem, s. 2, Sejm ekstraordynaryjny dwuniedzielny... Śmierć króla nastąpiła 1 lutego nad ranem, w przeddzień święta Matki Bożej Gromnicznej.

109 Ibidem, s. 5, Relacyja śmierci nieśmiertelnej...

110 „Kurier Polski” 1733, nr 163.

111 B.Czart, rkps MNK 32, s. 6, Relacyja śmierci nieśmiertelnej...

1122 lutego przypadało święto Matki Bożej Gromnicznej, spierano się intensywnie o sposób zakończenia obrad sejmowych. B.Oss, 3577 II, k. 21 v.

113 B.Czart, rkps MNK 32, s. 6, Relacyja śmierci nieśmiertelnej... 
mi ministrami i senatorami. Niewiele wiadomo o jego otoczeniu w trakcie ostatnich dni życia; składała się nań przede wszystkim drezdeńska ekipa, którą przywiózł wraz z sobą i ulokował w Pałacu Saskim. Byli tam cieszący się zaufaniem sekretarz króla Thioly oraz H. Brühl określany mianem „intimus consiliarius", który - jak się wydaje - mógł bez ograniczeń przebywać w królewskich apartamentach, a także przekazywał zainteresowanym wieści o aktualnym stanie zdrowia władcy ${ }^{114}$. Monarcha umierał odizolowany od swych polskich poddanych, co różni jego śmierć od zgonów poprzedników, zwłaszcza Zygmunta III Wazy ${ }^{115}$. Paradoks polegał na tym, że sporo owych szlacheckich poddanych było obecnych w stolicy w związku z toczącymi się obradami sejmu ${ }^{116}$.

\section{Wnioski}

„Żył królem, [a] umarł człowiekiem” zanotował Wespazjan Kochowski o zgonie Michała Korybuta Wiśniowieckiego ${ }^{117}$. Analizowane przykłady agonii kolejnych polskich monarchów pokazuja, że choć umierali oni w otoczeniu dostojników, lekarzy i duchownych, to ich śmierć miała przede wszystkim ludzki wymiar. Za każdym razem umierał człowiek będący czasowym dysponentem majestatu i dostojeństwa (jego elementem była bardziej tradycyjna niż religijna sakralizacja władzy), które jednak nie ginęły wraz z każdorazowym monarchą, ale trwały wraz z Rzeczpospolitą i były przekazywane jego następcy na tronie. Ciało króla było tylko tymczasową inkarnacją majestatu, co wyjaśnia fakt, dlaczego współcześni nie odczuwali żadnych oporów chociażby przed dokonywaniem sekcji zwłok monarchów po śmierci (wszyscy monarchowie, których oprawa śmierci była przedmiotem analizy w niniejszym studium, zostali poddani autopsji).

114 Ibidem, s. 2, 4.

115 O śmierci tej napisano m.in. „tak [...] odarty z majestatu we własnej duszy, osamotniony pośrodku własnych poddanych, ze smakiem wina na ustach i podziału Polski w mózgu, umarł August II”. Zob.: S. Askenazy, op. cit., s. 57.

116 „Kurier Polski” 1733, nr 164.

117 W. Kochowski, op. cit., s. 359. 
Oprawa królewskich śmierci w XVII i XVIII wieku była bardzo różna, zależna od osobowości władcy, jego aspiracji, ale i od królewskiego otoczenia. Wspomniana teatralizacja śmierci stanowiła do pewnego stopnia wynik obecności dworu i reguł rządzących dworskim życiem, w tym pieczołowitości w przestrzeganiu ceremoniału. Podobnie jak we Francji, w Rzeczypospolitej nie istniał sztywny kanon zachowania w obliczu śmierci monarchy, miano raczej pewne ogólne wyobrażenia związane z tym faktem. Zaliczała się do nich obecność najważniejszych osób w państwie przy boku umierającego króla, przy czym był to oblig dotyczący przede wszystkim stronników monarchy oraz biskupów i ministrów przebywających w tym czasie w stolicy. Równie istotna była pieczołowitość w wypełnieniu chrześcijańskich obowiązków przez umierającego - monarcha był drobiazgowo i skrupulatnie przygotowywany do śmierci ${ }^{118}$.

Nie ulega natomiast wątpliwości, że agonia króla stanowiła zawsze okazję do załatwienia zarówno spraw państwowych, jak i prywatnych interesów. Element ten jest zauważalny w przypadku wszystkich trzech analizowanych zgonów. Często to on właśnie decydował o tym, że kolejne etapy królewskiej śmierci były rozgrywane przez monarchę i jego otoczenie niczym dobra teatralna sztuka (Zygmunt III), stawały się narzędziem walki politycznej już po jego śmierci (Jan III Sobieski) bądź też powodowały całkowitą izolację władcy od rozpolitykowanego otoczenia (August II Sas). Równie charakterystyczne są dążenia do kontroli przepływu informacji o stanie królewskiego zdrowia przez najbliższe otoczenie umierającego monarchy, a nawet tendencja do dezinformowania opinii publicznej w tym względzie. Cele tych zabiegów były zróżnicowane, zazwyczaj chodziło o nierozbudzanie niepotrzebnych emocji bądź walki o wpływy.

W Rzeczypospolitej nigdy nie nastąpiła teatralizacja śmierci królewskiej na podobieństwo monarchii francuskiej (decydująca była w tym względzie odmienna rola dworu w obu państwach). Nawet dwukrotna ceremonia pożegnania Zygmunta III z poddanymi nie może być zaliczona do tej kategorii wydarzeń. Agonia polskiego władcy z pewnością nie była spektaklem, w którym to majestat odgrywałby główną rolę; wręcz przeciwnie była ona za każdym razem na wskroś przesiąknięta pierwiastkiem ludzkim.

118 Por.: La mort de rois..., s. 16, 29-41. 
Polscy władcy elekcyjni byli przecież królami za życia, w momencie śmierci pozostawali tylko ludźmi.

\section{Theatre and majesty. Three examples from the history of the Commonwealth of Poland and Lithuania in $17^{\text {th }}$ and $18^{\text {th }}$ centuries}

(Summary)

The article refers to the circumstances of deaths of the Polish kings, especially Zygmunt III Waza, Jan III Sobieski and August the Strong. The analysis is focused on the time and place of those deaths and especially, on the persons surroundings the kings during the last minutes of their lives. It turns out that these moments were more human and religious than majestic event and only in the case of Zygmunt III Waza the farewell ceremony was organized.

The circumstances of deaths were various and depended largely on the personality of monarchs. The agony of the king was many times an excellent occasion to pursue some personal interest. That was why in the case of death of Zygmunt III Waza the closes and senators were intentionally misinformed on the royal health; after the death of Jan III Sobieski the struggle for power was launched and at the same time August the Strong was isolated from his Polish subjects during his agony.

Katarzyna Kuras

Uniwersytet Jagielloński, Instytut Historii e-mail: katarzyna.kuras@uj.edu.pl 